\title{
War, Displacement, and Refugeehood Existential Encounters of Religion in the Syrian Refugee Crisis
}

\author{
INGRID LØLAND \\ VID Specialized University, Norway
}

ABSTRACT How and to what extent does religion play into the life-rupturing experiences that characterize forced migration? This article provides a novel look at how issues of religion and identity (re/de)constructions are entangled with the Syrian refugee crisis and mirrored in the diverse experiences relating to a sample of Syrian refugees now residing in Norway. The study aims to delve more deeply into the Syrian scene of war as a determinant backdrop to the Syrian refugee crisis, thereby tracing the intersection of religion in people's experiences of conflict, displacement, and refugeehood. It argues for a lived dimension approach when analysing the variable ways in which empowering and disempowering aspects of religion cut into their migration trajectories. Additionally, it applies a theoretical lens derived from existential anthropology to explore how narrative negotiations veer between chaos, crisis, and disruption, on the one hand, and resilience, hope, and restitution, on the other. The study reveals an ambiguous empirical reality in which the nexus between religion and forced migration involves highly contradictory identification processes. Furthermore, it provides vivid polyvocal testimonies on how Syrians have navigated the liminal in-betweens of vulnerability and agency in their escape from Syria as well as during their journeys of displacement into refugeehood.

KEYWORDS Syrian war, Syrian refugee crisis, religion and identity, existential anthropology, vulnerability and agency, narrative research

\section{Introduction}

"Most of the war in Syria is wrapped under a religious cover."

"I think this is the worst feeling one can have, to arrive at a point where you feel that your life story has ended."

"It was fear on all the roads leading out of Syria." 
"The problem is not religion; the problem is how people use religion."

Forced migration-from the time of escape to relocation in exile-may be seen as a profound series of existentially charged and liminal moments intersecting the experiences of refugees at every stage of their journey. How and to what extent does religion play into the life-rupturing experiences that characterize forced migration? The following study aims to provide a fresh look at how issues of religion and identity (re/de)constructions are entangled with the Syrian refugee crisis and mirrored in the diverse experiences of Syrian refugees residing in Norway. ${ }^{2}$ It intends to explore multifaceted aspects of pre-migratory and migratory trajectories prior to resettlement in Norway. Despite increased attention in academic literature, the nexus surrounding religion and forced migration in a Syrian refugee context has yet to be more thoroughly researched, not least from the insiders' point of view of Syrian themselves.

Unpacking the role of religion in the migration trajectories of Syrian refugees may appear a daunting task. This is because the Syrian refugee crisis is the result of an exceptionally complex and internationalized civil war where issues of religion are but one of many conflicting components caught up in its intricate web. Additionally, the ways in which religion intersects the various stages of Syrian refugee journeys produce a plurality of responses and display both deeply personal testimonies and collectively shared experiences. Not to mention that 'religion' itself is a highly contested concept that lends itself to multiple understandings as to how it has triggered, informed, and otherwise dynamically (re)shaped experiences of Syrians displaced by conflict and war.

These challenges notwithstanding, the present paper argues for a narrative approach in which polyvocality and existential dimensions are viewed as a means of eliciting multiple voices and encounters of religion within the shared phenomenon of forced migration. This includes how lived religion, in a broad sense of the term, dynamically plays into emotionally charged "moments of being" and experiences of rupture (Jackson and Piette 2017). Applying an existential lens allows for a "zooming in on individuals' lifeworlds" (Lems 2016, 315) and seeks to provide a deeper understanding of how people, through storytelling, make sense of the tensions and paradoxes of conflict-induced displacement. Embedded in this dynamic framework is a multifaceted analysis of religion's (dis)empowering aspects; its ability to comfort, motivate, support, and secure identities, on the one hand, and its capacity for control, exclusion, violence, and the destabilization of identities, on the other.

This article is divided into five parts. The first provides some methodological reflections on the use of polyvocality in narrative research as a preferred approach of this study. The second part offers a backdrop for developing a more refined understanding of lived religion and fluctuating identity discourses in a Syrian refugee context. Part three suggests that existential anthropology provides an interesting theoretical vocabulary through which refugee experiences with religious encounters can gain voice and nuanced expressions. Bridging ex-

$1 \quad$ Quotes are taken from interviews conducted with Syrian refugees in exile and will be narratively contextualized later in this paper.

2 It should be noted at the outset that the term 'refugee crisis' has been debated and criticized in academic circles on the basis of its (mis)use in political and mediatized discourse (Crawley and Jones 2020; Wilson and Mavelli 2017; Matar 2017). Rather than understood as descriptive of a crisis for refugees, the term is often associated with problematic inflictions on European nation-states. Although it is important to reflect on the narrative uses of this term, this study employs the term specifically in relation to the Syrian refugee context. It thus attempts to view the 'crisis' in a twofold way: First, as a more generic term for the mere magnitude of the refugee exodus that has befallen the nation of Syria, and secondly as an existential term indicating chaos, disruption, and disorder as experienced and narratively conveyed by individual Syrians. 
istential theory with a narrative approach, this section borrows Arthur W. Frank's narrative typology of chaos, quest, and restitution and uses it as a tool for the ensuing analysis. Finally, the last two chapters present two narrative clusters of the empirical material in which religion's entanglement in the spatio-temporal trajectories of war and forced displacement is scrutinized more closely. Part four deals with narratives of escape from Syria, and part five with migratory journeys into refugeehood.

\section{Polyvocality and Narrative Inquiry: Methodological Reflections}

Talking to Syrians face-to-face has turned out to be a tremendous eye-opener for the multivoicedness that inhabits refugee stories. Consequently, in this study, I have strived to include a broad sample of voices that mirror the heterogeneous Syrian refugee population residing in Norway. The motivation behind this inclusiveness is partly to challenge the marginalization of refugee voices in general, as well as to address the often polarized depiction of Syrian refugees as either vulnerable victims or political liabilities in mediatized discourse (Wilson and Mavelli 2017; Matar 2017). ${ }^{3}$ By moving away from such dichotomies, speaking singularly of "the migrant" (Frederiks 2016, 186) or "the refugee experience" (Lischer 2014, 249) is detrimental to the diversity of human displacement stories. When individual stories recede into the background or become concealed behind simplistic depictions, representation falls short of ensuring the more nuanced and plural first-hand accounts of refugees are given public attention.

In line with other scholars, I concede that combining a polyvocal approach with narrative inquiry might serve as a particularly useful tool for contesting generalizations as it endeavors to encapsulate complexity and diversity in human experiences (Eastmond 2005; Manojlovic 2010; Daiute 2014; Sigona, Nando 2014; Bamberg 2016). Polyvocality means to incorporate many voices to endorse diverse listening and present multiple points of view. Narrative inquiry is a way of grasping an emic or insider's view and understanding the meanings people ascribe to life as lived. Henceforth, the inclusion of multiple voices in this study has served two purposes. On the one hand, it has allowed a broad sample of the heterogeneous Syrian refugee population in Norway to be heard. On the other hand, polyvocality is a powerful reminder that any one refugee story necessarily invokes the voices of others, reminiscent of what Bakhtin called the 'heteroglossic' and 'polyphonic' nature of narratives (1981). Socioculturally, I have regarded these two dimensions of polyvocality-i.e. multivoicedness among different Syrian nationals and within each Syrian's individual story-as valuable for encountering Syrians in expanded and more comprehensive ways.

By transcending the borders between the social and the individual dimension in narrative, we may be better equipped to understand forced migratory experiences as occurring on both micro and macro levels, including their embeddedness in matters of existential importance. Existentialism's intimate relationship with the philosophical tradition notwithstanding, 'existential' is here understood more anthropologically as an expression of the nuanced and lived dimensions of human experiences (Jackson and Piette 2017, 6). Existential anthropol-

3 See also UNESCO Website. Accessed March 26, 2021. https://en.unesco.org/news/media-and-migrationcovering-refugee-crisis; Refugees Reporting Website. Accessed March 26, 2021. https://www.refugeesrepo rting.eu/wp-content/uploads/2017/10/Changing_the_Narrative_Media_Representation_of_Refugees_a nd_Migrants_in_Europe.pdf; uib Website. Accessed March 26, 2021. https://www.uib.no/node/95377/97 875/refugee-crisis-figures-and-media-image; Ethical Journalism Website. Accessed March 26, 2021. https: //ethicaljournalismnetwork.org/moving-stories-international-review-of-how-media-cover-migration 
ogy views human life as unfolding dynamically "en passage between different narratives and worldviews, as well as different modes of being," whether they occur in everyday situations, during critical events, or in charged moments (Jackson and Piette 2017, 9). Thus, peoples' (life)stories present us with abundant material for analyzing experiential and existential contexts. These contexts are inherently polyvocal and ambiguous, as they not only provide access to the variety of meanings individuals ascribe to their experiences, but also function as a gateway into broader cultural and social frameworks that shape the way people make sense of their experiences (Miller and Glassner 2016; Castles 2012).

The overall intention of my project has been to engage empirically with multiple Syrian refugees residing in Norway and delve into their stories to get a more profound sense of the variations and complexities inherent in their life trajectories. More specifically, I have aimed to elicit stories that illustrate ways in which religion and issues of identity play into experiences of war, migration, and refugeehood. The unit of analysis employed in this research attempts to reflect such diversity by including participants whose ethno-religious backgrounds range from Sunni-Arabs and Kurds to members of various Shiite sects, and representatives of different Christian denominations. Some research participants also profess atheism or secular identity affiliations, and they all differ in age, gender, educational background, and geographical locations. What they have in common are their Syrian nationality and their refugee-status-most having arrived in Norway during 2015. To meet the target groups, both purposeful and snowball sampling helped find and recruit the twenty-eight Syrian participants in various Norwegian locations. All were informed of and gave consent to the research project's ethical standards, ensuring anonymity and confidentiality. ${ }^{4}$ During 2017 and 2018, in-depth interviews, focus group discussions, and informal conversations took place to shed light on a plurality of different perspectives regarding how religious issues operate in Syrian migration stories. ${ }^{5}$

\section{Understanding Religion and Identity in a Syrian Refugee Context}

Syria's ethnic and religious divisions may be described as a demographic mosaic that has been part and parcel of the country's long history of coexistence and conflict. According to pre-war estimations of the Syrian population's religious composition, roughly $75 \%$ belonged to Sunni Islam, $10 \%$ to the Alawites, $10 \%$ to Christian denominations, and the remaining 5\% to various Shiite, Druze, Ismaili, and Yezidi communities (Nome 2016). To these estimates must be added a great variety of divisions within many of these groups. Despite deep-seated knowledge of living peacefully with diversity, Syrians have for the past few decades increasingly lacked a script with which to articulate relational tensions inherent in Syrian society. This may partly be attributed to the authoritarian climate of fear that has exerted an unimaginably tight control over the public expression of political and religious identities (Wedeen 2015; Bali 2015; Stolleis 2015; Yassin-Kassab and al-Shami 2016; Pearlman 2016; Sørvig 2017; Van Dam 2017). The silencing on these topics has not only exacerbated anxiety about what can be spoken of, but it has also disallowed constructive ways of dealing with difference.

The revolution and emerging civil war triggered divergent responses to these latent iden-

\footnotetext{
4 Prior to the interviews, the Norwegian National Research Ethics Committee (see https://etikkom.no/en/) approved the research.

5 The interviews were conducted in a mix of the Arabic, English, and Norwegian languages. In conjunction with the author, a research assistance with no affiliation to Syria helped to translate and transcribe conversations conducted in Arabic.
} 
tity conflicts in Syria. One the one hand, they spurred a sense of unity and relief for breaking away from the two Alawite-dominated Assad-regimes and their coercive silencing on subjects previously considered taboo. On the other hand, they articulated progressively more sectarian attitudes to rise to the surface of public discourse (Løland 2019a). Hence, new dividing lines (re)emerged between Sunnis and Shiites, Muslim and Christians, the Alawite-dominated regime and religio-political opponents, majority and minority communities, proponents of liberal and extremist beliefs, local and foreign loyalties, etc. According to Hugh Lovatt (2013), the war erased the nationalist glue that previously held the region's heterogeneous societies together. What we have been seeing in Syria, he says, "is bringing to the fore loyalties and linkages that run deeper than state borders" $(2013)^{6}$, causing the breakdown of national identity into tribal, religious, and ethnic identities. As the conflict evolved from an initially secular and revolutionary revolt against the Assad regime towards ever more complex and multifaceted dividing lines, religion became increasingly intertwined with other conflict-producing factors. ${ }^{7}$ With this backdrop in mind, there is a need to enhance our understanding on how religion and identity issues have played a role both prior to and during the Syrian refugee crisis. The mere scale of this humanitarian displacement crisis, the world's largest since World War II, attests to the urgency of getting a more nuanced look at these matters. ${ }^{8}$

In order to understand the range of experiences and responses to religion as mediated in the narratives of Syrian refugees, there are a few important issues to consider. First, we need to recognize that the Syrian refugee crisis results from a particular form of migration caused by armed conflict, civil war, and violent uprooting. Thus, when considering that conflictinduced displacement and forced migration represent a specific type of category within the broader phenomenon of migration, we need a more complex and sophisticated understanding of how religion intersects with these processes. Secondly, the Syrian refugee population is highly heterogeneous and has both controversial ideas about and varying degrees of affiliation to particular ethno-religious identities and religious issues. We must therefore shift away, as suggested by Khatereh Eghdamian (2016), "from the tendency to homogenize religious affiliations and identities and to engage with the complexities and challenges of religious heterogeneity" $(2016,450)$. There is thus a need for a dynamic framework of interpretation more sensitive to the plurality of voices and lived experiences of Syrian refugees. Thirdly, and due to the above considerations, the terms 'religion' and 'identity' must be broadened and elasticized, so to speak, to meet the multiplicity of lived realities and the dynamic space of the field. By avoiding viewing them narrowly, we may embrace the socio-cultural, political, and existential dimensions of these terms.

6 See Lovatt (2013): Your Middle East Website. Accessed March 26, 2021. https://yourmiddleeast.com/201 3/11/06/the-conflict-in-syria-is-bringing-to-the-fore-loyalties-and-linkages-that-run-deeper-than-stateborders/.

$7 \quad$ A new qualitative study by the Norwegian Center for Holocaust and Minority Studies (2020) compares the impact of ethno-religious components in the flight stories of Iraqi and Syrian refugees residing in Norway. While identity figured as a prime reason for seeking refuge among the Iraqi refugees, the Syrians were less inclined towards explaining their escape along religious fault-lines. However, the report confirms that ethnic and religious divisions became more frequent as the conflict evolved and that a majority of those interviewed blamed the political regime for exploiting such divides as part of its war tactics. See "Flight from Iraq and Syria. The Impact of Religious and Ethnic Identity" (2020): Inclusive Citizenship Website. Accessed March 26, 2021. https://www.inclusive-citizenship.no/wp-content/uploads/2020/03/HLReport-flight-from-iraq-3.pdf.

8 According to updated numbers by the United Nations Office for the Coordination of Humanitarian Affairs (OCHA), the Syrian crisis has created more than five and half million refugees and displaced a further six million Syrians inside their own country: Unocha Website. Accessed March 26,2021. https://www.unocha .org/syrian-arab-republic/about-ocha-syria. 
When reconceptualizing religion in relation to forced migration, we may discern at least three different uses of the term 'religion' in the interlocutors' stories: as an ascribed category, on a discursive level, as well as on the level of lived experience. Particularly the two latter usages will be scrutinized against the polyvocal and existential approach applied in this study. The term "lived religion" (McGuire 2008; Ammerman 2016) functions as a fruitful vantage point here as it is concerned with "ordinary people" and "everyday life," rather than the institutional and doctrinal aspects of religion (Ammerman 2016, 7-9). The personalized dimensions of how religion is experienced are thus of compelling value for our investigation into the empirical variations of Syrian refugee stories. As Nancy Ammerman has shown, the field of lived religion encompasses a multidimensional approach in which the embodied, material, placed, cognitive, emotional, and discursive aspects can be further explored (2016, 10-11). However, we might do well to adjust the "everyday" dimension of religion in forced migratory conditions, as religion-related encounters, experiences, and discursive expressions are situated in extraordinary settings, rather than in the trajectories of day-to-day normalcy. Hence, when capturing how religion simultaneously operates in ways both extremely empowering and resourceful as well as disempowering and destructive, the lived dimension must be wary of entanglements and tensions that occur in involuntary or coerced circumstances. Not least do we need to research beyond these frames of polarization and find a vocabulary that encapsulates the in-betweens of vulnerability and agency in relation to religious encounters.

Similarly, this study seeks to broaden the notion of identity and its relation to human subjectivities that fluctuate in the fuzzy and everyday realm of 'lived religion', particularly in the context of forced migration. Moving away from an essentialized understanding, I adopt the now increasingly prevailing view of identity as something "never complete, always in process" (Hall 1990). As suggested by Stuart Hall (1990), the term 'identification processes' may better signal the dynamic and continuously shifting dimensions of identity constructions. Roger Brubaker and Frederick Cooper's (2000) apt characterization of identity as a phenomenon that manifests itself individually and collectively through cognitive means, discourses, and social practices echoes this understanding. They approach identity not merely as an analytical category, but also as a category of practice; in other words, as an "everyday social experience, developed and deployed by ordinary social actors" (2000, 5). Moreover, in the Syrian refugee context, a more multi-layered understanding of identity needs to be spelled out in order to avoid over-essentializing the role of religion for all refugees at all times (Beaman, Selby, and Barras 2017). Indeed, for many Syrians, ethno-religious identities may be significant but are usually not considered an all-encompassing aspect of a person's social being. As discussed by Annika Rabo (2012), “[c]lass background, region or place of origin, profession, clan or kin group and political affiliations are equally important in how Syrians present themselves and in how they classify others" $(2012,83)$. Again, however, it is worth noting that in times of conflict, cultural, religious, and political identifications tend to rise more acutely to the surface, igniting felt and imagined tensions at the macro and micro levels of society. Experiences of uncertainty and upheaval may thus motivate individuals and groups to secure their identities, demarcating boundaries in terms of in-group and out-group belonging (Demmers 2017; de Fina and Tseng 2017; Hermans and Dimaggio 2007). Notably, in religion-related conflicts, patterns of identification and dis-identification may enhance the framing of differences, potentially legitimizing violence (Brubaker 2015; Demmers 2017; Van Liere 2009, 2011). On the other hand, religion can just as well inform, validate, and sustain moral values and peaceful coexistence, endorsing unifying identification processes (Van Liere 2009). 
In order to understand these overlapping and contradictory tendencies inherent in the Syrian refugee accounts, I believe that an existential approach will provide more nuanced perspectives on the nexus between religion and identity in the context of conflict-induced displacement.

\section{Chaos, Quest, and Restitution: Existential Perspectives on Religion and Refugeehood}

\section{Religion and the Anthropology of Existence}

Religion and migration intersect in a myriad of ways. When people are on the move, so is religion; it operates across borders and time and space. Over the past few decades, research into religion and migration have facilitated new interdisciplinary perspectives, many of which are instrumental to understand how faith, spirituality, and religious teachings and practices are integral to globalized migration flows and transnationalism (Ebaugh and Chafetz 2002; Tweed 2006; Levitt 2007; Vasquez 2008; Hock 2008, 2011; Ebaugh 2010; Levitt, Lucken, and Barnett 2011; Hagan 2012; Wong 2014; Pine 2014; Beckford 2015; Frederiks 2016; Drønen 2018). However, whereas previous research has devoted less attention to the particularities concerning religion and forced migration (Godžiak and Shandy 2002), the current refugee crisis has spurred the need for a closer examination of the many contradictory ways in which religion intersects with processes of displacement (Fiddian-Qasmiyeh 2020; Crawley and Jones 2020). This study will therefore theoretically engage with an existential lens to the ensuing narrative inquiry into Syrian refugee stories.

Existential anthropology exemplifies a field of research that is particularly concerned with looking at the existential realm of human experiences: "its strangeness, its ambiguity, its fundamental unfathomableness-in other words, its humanity" (Denizeau 2017, 231). Inspired by philosophical existentialism, one of this approach's key features, as Michael Jackson and Albert Piette (2017) espoused, is grasping the nuanced complexities of "life as lived" (2017, 3). In more elaborate detail, it deals with:

(...) a determination to explore the variability, mutability, and indeterminacy of that lived reality as it makes its appearance in real time, in specific moments, in actual situations, and in the interstices between interpretations, constructions, and rationalizations, continually shifting from certainty to uncertainty, fixity to fluidity, closure to openness, passivity to activity, body to mind, integration to fragmentation, feeling to thought, belief to doubt. (Jackson and Piette 2017, 4)

When applying an existential approach to experiences of religion and identification processes in forced migration, I strive for a more sensitive and open awareness of the many contradictions, simultaneities, and inconsistencies that envelop the stories people tell. According to Alan D. DeSantis (2001), we need to move away from unidimensional assumptions regarding refugees and exiles, and instead allow for "the dialogical tensions" inherent in their experiences to be heard on their own terms (2001, 3 and 16). Applying an existential lens, therefore, means looking at how different forces in life operate dynamically and drive forth "the possibility of contradicting ideas existing simultaneously" (DeSantis 2001, 1).

Religion, as understood in the framework of existential anthropology, is less seen as a conventional category than a multiplicity of practices and modalities of belief, reflected in what 
William James once called "the varieties of religious experience" (1985). Rather than treating religion as synonymous with a set of shared homogeneous representations, an existential exploration is concerned with its diversity, inconsistency, and its variable relevance for each experiencing subject. Similar to the concept of "lived religion" (McGuire 2008; Ammerman 2016), Jackson and Piette call for a "polythetic" approach to religion, which recognizes this variability and ambiguity in everyday existence $(2017,13)$. Furthermore, when viewing religion existentially, we need to acknowledge its relation to issues of human security, especially in moments of transition, risk, and uncertainty (Giddens 1991; Thomassen 2014; Bartels et al. 2015). This includes how people, in the existential quest for making sense of disruptive life-courses, secure identities and maintain boundaries.

A narrative lens may accentuate these existential border phenomena most powerfully. Storytelling functions as meaning-making and discursive practices "within which we fashion, refashion, rework, navigate, construe a sense of who we are" (Bamberg 2016). Alongside experiences of suffering, loss, and struggle coping with physical and mental dislocations, refugee stories also convey hope, imagination, agency, and achievement. Thus, while intense experiences of uncertainty, anxiety, and danger can act as supreme clauses for negativity, it can also inspire people to open spaces for possible actions (Holbraad, Kapferer, and Sauma 2019). A fundamental tenet in this "struggle for life," according to existential anthropology, is to "understand the resilience of the human being in the multitude of situations that attempt to deny its existence" (Denizeau 2017, 224). Such a perspective, therefore, demands a willingness to grasp the complex interconnections between vulnerability and agency in displacement stories. In the following section, I shall return to some of these ideas when applying Frank's narrative typology in the Syrian refugee context.

\section{Arthur W. Frank's Narrative Typology}

In The Wounded Storyteller ([1995] 2013), and in other publications, Frank provides an intriguing narrative typology transferrable to my inquiry into the polyvocal and existentially charged trajectories of Syrian refugees. Initially, his research is concerned with patients' narrative perspectives and how experiences of illness propel a need to make sense and meaning through storytelling. Frank lists three core typologies in stories of illness: narratives of chaos, quest, and restitution.

Chaos narratives can mirror experiences of trauma and extremity in which no future is imagined, and the present is but a crater of hopelessness. These narratives are, in fact, "antinarratives," according to Frank, since chaos "is always beyond speech" ([1995] 2013, 101) and tends to resist narrativization. As such, "chaos is the ultimate muteness that forces speech (...) to catch the suffering in words" ([1995] 2013, 102). After experiencing chaos, it will remain in the background, according to Frank, and although these stories can be hard to transcend, they "must be accepted before new lives can be built and new stories told" ([1995] 2013, 109).

Quest narratives see illness as a journey with meaning and purpose. They are reminiscent of a mythical hero who must surpass several trials and thresholds to transition into new and altered states of being. Frank calls them the "holy grail" of stories, intimately tied to a "hope that all this questing - or displacement in psychoanalytic terms - might someday end; that there is a telos, a finish line, a homecoming after which no travel is necessary" $(2010,57)$.

Finally, restitution narratives are placed on the opposite end of chaos stories. They are concerned with restoring those who are ill to health and returning people to a sense of status 
quo, to a future that fixes the present disease by restoring the normalcy of the past. It is a narrative of survival and compelling strength, yet, Frank warns, restitution narratives may also fall short of denying reality and turn into preferred cultural scripts that gloss over or otherwise pressure forth an idealization of the past (2008, 84-85).

For our purposes, and far from labeling refugeehood an illness, the useful analogy lies in the fact that both illness and forced displacement are disruptive events that severely destabilize the coherency of one's life story. Both entail the emotionally distressing elements of trauma and of being thrust into the unknown beyond one's immediate control. Frank's description of illness as bodily and mental "shocks of having life rearranged" ([1995] 2013, 190) is thus not a far cry from the existential turbulence violence and uprootedness inflict. Certainly, the analogy may even be more profound as war, conflict, and displacement can themselves cause physical and psychological wounds comparable to the more conventional conceptions of illness and injuries.

In the Syrian refugee context, chaos is perhaps one of the more apt expressions for encapsulating the many layers of complete disorder and confusion prevalent in refugees' oral testimonies. Indeed, chaos is a term frequently used to describe the Syrian conflict thanks to its violence and the ruined remains of a country millions of people have left behind. Chaos, then, is a description that invokes both severe upheavals and disruption on an overall structural level as well as on a subjective and experiential level. However, it would be a grave and one-dimensional misapprehension of the empirical material at hand to reduce Syrian refugee experiences merely to the realm of chaos. Instead, what we need is a readjusted understanding of chaos in terms that resonate more accurately with the experiential world in the refugees' own stories. For such an understanding to materialize, we need analytical tools to capture existential complexities more dynamically and address the "messy lived realities and subjectivities" (Day and Lee 2014, 352). Whereas chaos and rupture may be viewed as inherently harmful forms of discontinuity, there is a "dual aspect" to consider, namely that it can also "act as a positive or dynamic impulse towards escape, redirection, reconstitution and sometimes renewal" (Holbraad, Kapferer, and Sauma 2019, 1).

In the following two narrative sections, we shall acquaint ourselves with a segment of the Syrian refugee population who have shared their experiences of war, migration, and refugeehood. By conversing with existential anthropology and applying Frank's narrative typology, the ensuing empirical analysis provides a novel framework for an existential exploration into religion and forced migration. At the outset, it may be determined that chaos, quest, and restitution are dynamic and overlapping categories invariably at play in Syrian migration trajectories. However, we need to be mindful they may not all be equally represented in the collected stories of escape and refugeehood. Additionally, in Letting Stories Breathe (2010), Frank shows another captivating feature of stories relevant to my inquiry. Echoing Bakhtin, and contrary to a linear understanding of stories as having a clear-cut beginning, middle, and end, Frank stresses the narrative disorder and the indefinite nature of stories. Rather, he says, any story is "a portal" into other stories (2010, 37), resonating "multiple truths that have respective claims to expression" $(2010,41)$. This interpretative openness is of compelling value for my investigation into how chaos, quest, and restitution play out in the Syrian refugee context. 


\section{Leaving Syria: Narratives of Escape}

When listening to stories the Syrian refugees tell, it is easy to be overwhelmed by the torrents of traumatic experiences that follow war, violence, and forced displacement. Indeed, after years of relentless fighting, there are numerous reports from UN-sanctioned investigative bodies and other NGOs declaring "overwhelming evidence of war crimes in Syria." 9 This violent backdrop to the Syrian refugee crisis is essential to acknowledge when revisiting the research question of this article. To understand how issues of religion and identity (re/de)constructions are entangled in Syrians' refugee trajectories, it should be recognized that stories of forced displacement, although sharing many similarities, are deeply personal and originate from different reasons, places, and times. In this narrative section, a sample of individual voices discursively shares encounters with and experiences of related religious issues in migration contexts before leaving Syria. ${ }^{10}$

\section{Sectarianization and Mistrust}

Maryam, a Christian Orthodox woman from Damascus, left Syria when bombs shattered her neighborhood, and the immediate threat of death and destruction became too great to endure. Added to this violent backdrop, she paints a grim picture of an increasingly toxic atmosphere that she said was "infesting all Syrians from inside." It involved discussions about religious identities and political allegiances and spurred conflicts that eventually separated friends and family members. Before the war, Maryam's friends comprised Muslims and Christians alike: "We were together, celebrating everything together, sharing life, supporting each other." However, this togetherness slowly evaporated during the war and gave way to separation and mistrust. For Maryam, such experiences were inevitably connected to her minority status as a Christian amidst a majority Muslim culture:

We are not Islamophobic, no - but we have problems with the Islamic culture. [...] Actually, we Syrians have a problem with each other. We don't have a problem with the government, really, but we have a problem with respecting each other. [...] The problem is not religion; the problem is how people use religion.

Said echoes similar processes of sectarian estrangement. A Sunni Muslim who lived in the suburbs of Damascus when the war broke out, multiple factors motivated Said to leave Syria that had accumulated over several years. He explains how "the war and the endless bombings" increasingly affected going about daily life. "Just going out of the house was terrify-

This evidence implicates all parties in the conflict and attests to an extraordinarily grim record regarding the violations of human rights and international humanitarian law. For example, see Human Rights Watch Syria World Report 2019. Accessed March 26, 2021. <www.hrw.org/world-report/2019/countrychapters/syria $>$. Violations may include severe and indiscriminate attacks against civilians; inhumane treatment; kidnappings and summary executions; torture, rape and gender-based violence; arbitrary arrests and enforced disappearances; the use of unlawful weapons; destruction and pillaging of property; mass deportations and the restriction of civilians' ability to flee hostilities. See The International Observatory of Human Rights, March 2018. Accessed March 26, 2021. https://observatoryihr.org/news_item/overwhelmingevidence-war-crimes-syria/. Another useful resource are the various reports and documentations by the Independent International Commission of Inquiry on the Syrian Arab Republic, sanctioned through the United Nations Human Rights Council. Accessed March 26, 2021. https://www.ohchr.org/EN/HRBodies/HRC/IICI Syria/Pages/IndependentInternationalCommission.aspx.

10 Lack of space allows only some of the voices belonging to the twenty-eight participants who took part in this study to receive attention in this paper. Thus, a selection of narrative excerpts was based on the most relevant themes discussed in relation to this paper's research question. 
ing," he says, not to mention the numerous checkpoints one needed to pass in order to move around. Living in a predominantly regime-friendly area, according to him, passing the security checkpoints became ever more hazardous as the regime soldiers' sectarian resentment often characterized these encounters. "I was suddenly regarded as a threat," he explains. "You are subject to being imprisoned or kidnapped in any place, you can be taken by any party, and I experienced this twice."

Bassem, an atheist of Christian Orthodox origin, provides a contrasting, albeit ambiguous perspective on passing the checkpoints when perceived to hold a Christian identity. He admits that living in an area dominated by Alawites gave him some leverage.

At the checkpoints, the guards would automatically let me pass because of my name and address on the ID-card. I didn't like to receive a privileged treatment because no one in my family has anything to do with the regime. But at the same time, it was a safe line for me because they were really angry and brutal people.

Whereas experiences of a prolonged war and massive destruction strike to the core of determining circumstances for the Syrian refugee crisis, these refugee stories reveal there are more underlying and overlapping aspects to consider. For many, religion and issues of identity are woven into their trajectories, pointing towards a contested space in which patterns of "identification and disidentification" generate polarized and conflictual categories (Van Liere 2009, 475). Said explains how military personnel perceived his Sunni identity as a "threat" and how he had no means of protecting himself against indiscriminate rhetoric and demeaning behavior at the hands of those in power. The same authorities treated Bassem differently because of his religious background. His story reveals the struggle of negotiating identities and allegiances amid conflict, and the discomfort he feels at being treated advantageously as a Christian by the regime with which he desired no association. Maryam draws a sharp line between life before and after the armed conflict and confirms what has been documented in several publications regarding an increased level of mistrust and deteriorating social relations (Stolleis 2015; SCPR 2015; Løland 2019b). While bewailing the lack of trust and respect among Syrians, she is also wary of the way religion is used, or rather misused, as a means of alienating one another. At the same time, the way Maryam refers to Islam is itself an example of how processes of sectarianization became integral to Syria's social degradation. These processes have not occurred in a vacuum but must be understood as a result of both political and socioeconomic factors in which (religious) violence and a culture of fear over decades have "shocked the collective consciousness" of the Syrian people. ${ }^{11}$

\section{Religion-Related Violence and Identity Othering}

Violence incited, perpetrated, or justified under the auspices of religion is an additional backdrop to the migration-determining factors for many of the interlocutors taking part in my study. Said experienced such violence firsthand when two opposing forces in the Syrian civil war kidnapped him. The first time, regime soldiers detained him at a checkpoint:

I was blindfolded and taken to a cellar in a military base they called "The Bakery." They kept calling me a terrorist and beat me for three hours. I still have the scars

11 Syrian Centre for Policy Research (SCPR): "Syria. Alienation and Violence: Impact of Syria Crisis Report 2014." Accessed March 26, 2021. https://www.scpr-syria.org/scpr-alienation-and-violence-report-20142. 
on my back. [...] They accused us [the Sunni Muslims] of murdering al-Hussein and demanded that I plead guilty and ask for mercy.

The second time, one of the many new Islamist opposition groups that had taken control of an area near Damascus captured Said. "I don't remember the name of this group, but they were all young guys, you know, wearing black headbands and the typical [salafi-style] clothes." They were all heavily armed and took Said at gunpoint while he was on his way to work. This time they accused him of working for the Mukhabarat-the regime's secret intelligence apparatus.

It didn't matter that I said I was a Sunni Muslim and that they could look at my ID or call my parents to verify my identity. They interrogated me for hours, and they beat me with thick cords and threatened to kill me. [...] Eventually, they brought me to an abandoned warehouse, and I was imprisoned there for four days. I could hear the constant sounds of gunshot and helicopters outside the building. [...] After a couple of days, three young guys were brought to the floor where I was kept, and I could tell they were soldiers from the army. The chief interrogator came and questioned them, and they were tortured too. [...] But in the end, they were shot in front of my eyes. Just like that. [...] I have never been more scared for my life because afterwards, he [the chief interrogator] told me that 'you are next.'

Said eventually freed himself from imprisonment by paying a ransom. "They were all into money, you know, that's all they cared about," he explains. Upon being released, the chief interrogator approached him and said, "Congratulations, you are alive! We thought you were an Alawite, but you are a good person."

Nourya was a young mother of two when the war descended on her neighborhood in Aleppo. As a liberal Sunni Muslim, she watched the religious turmoil in Syria with horror and dread. "We heard about these false Islamic groups who pretend to be Muslims, and you know, they are mostly Sunnis. I hate their kind of thinking!" Echoing both Maryam and Said, Nourya sees violent perpetrators' use of religion as a cover for other intentions and agendas: "Most of the war in Syria is wrapped under a religious cover," she claims, "but in reality, it all boils down to money and power." However, her resentment against religious bigotry is not only directed against Islamist groups, but includes the ruling regime and religious groups such as the Alawites and Shiites who she says justify their actions religiously:

They follow their sheiks and do whatever they say. They send their children to kill and believe they are doing it out of religion, but we, the Sunnis, our actions weren't due to religion because, in our religion, you cannot attack someone or do wrong to people. [...]

Bassem provides another perspective of religious-related violence he experienced at the beginning of the Syrian uprising. While studying in Homs, he was initially positively inclined towards the revolution and took to the streets with other students hoping to achieve political change. But when people called for jihad and demonstrations turned violent with religious overtones, he receded from the front lines and decided "this was not for me." He did not want to get more involved as "the Christians in Syria are really a peaceful people. The Church and everyone are like neutral, and they didn't take any side in the war". 
In my interlocutors' stories, what becomes palpable is that in times of conflict and social degradation, violence with religious undercurrents may take both rhetorical and physical forms; it may be perpetrated by outside forces and be reflected in people's conduct and the use of language describing "us" versus "them". Indeed, as Vamik Volkan (2006) has shown, violations in the name of identity, whether those identities are national, ethnic, religious, or ideological, tend to become massively traumatizing when applied to large-scale groups and in ways that devalue individuals based on their identity belonging. Said's story is a relevant example of these dynamics. Having survived two life-threatening events in which his religious-political identity was severely questioned, he describes the randomness of fear that accompanies such experiences of being 'othered,' regardless of the opposite stance of the perpetrators he encountered. In one incident, Said was accused of being complicit in the murder of al-Hussein, referring to the deeply divisive and inherited narrative of victimhood in the Sunni/Shia discourse (Manojlovic 2010, 6). ${ }^{12}$ He is thereby held collectively accountable for an alleged incident that occurred in the seventh century, showing how old clashes, whether real or fantasized, become reactivated in times of conflict (Volkan 2006, 16). Such stereotypical aspects of group identity attest to the volatile intersection of religious identity, history, and politics.

Similarly, we see both Nourya and Bassem are forced to take a stance that affects their identity affiliations. While Nourya portrays a clear contempt for religious extremism and "these false Islamic groups," she simultaneously compares her religious positioning to that of a generalized 'other'. She juxtaposes her form of Sunni Islam as superior to Alawites and Shiites, whom she accordingly perceives as being more prone to kill in the name of religion. Visible in her vocabulary is a sharpened boundary between ingroup and outgroup belonging based on religious authority. Whereas "they" - the Muslim others-are seen to blindly follow their religious leaders, "we"- the Sunnis in her story-follow a different moral guideline legitimized as "our religion". However, taking a meta-perspective on the Syrian conflict as a whole, Nourya views religion mainly as a cynical cover-up for economic power interests. Bassem, too, must reconsider his standing when confronted with an increasing 'Islamization' of the revolutionary call, deciding this was not what he had signed up for. Despite his self-declared position as an atheist, he seems to endorse a minority Christian view when describing all Christians as "a peaceful people" and the Church as neutral to the conflict. The Church may here be seen as authorizing certain acquiescing strategies in relation to Christians' noninvolvement in the conflict, although research shows that Syrian Christian political attitudes and perspectives on the war is more complex and differentiated (Fahmi 2018; Bandak 2014). Interpreted discursively, we may understand Nourya's and Bassem's stories as reflective of identity negotiations through which symbolic boundaries become socially constructed based on "collective narratives" about who people are and are not (Demmers 2017, 126).

On the whole, my interlocutors' negotiating practices are stark reminders of how the overwhelming forces of war, violence, and conflict push forth exclusionary identification processes and cut into the lived dimension of alienation and mistrust. Moreover, they are powerful testi-

12 al-Hussein - the grandson of the prophet Muhammad and the son of the fourth caliph Ali-was killed in the battle of Karbala (680 CE), at the hands of Yazid, the Umayyad leader of Damascus at the time. Commemorated annually, his suffering and death have received a central place in the history, tradition, and theology of Shia Islam. The incident galvanized the split between Shiite and Sunni Islam and has resurfaced in the Syrian civil war as a dividing narrative between regime-friendly Shia units and their Sunni opponents, often likened to the evil Yazid (see P. Smyth 2015. "The Shiite Jihad in Syria and its Regional Effects". The Washington Institute for Near East Policy. Accessed March 26, 2021. https://www.wa shingtoninstitute.org/policy-analysis/shiite-jihad-syria-and-its-regional-effects). 
monies of how pre-displacement experiences are filled with moments of existential risks and uncertainties, ambiguously impacting people's understanding of the variable role that religion plays in times of political upheaval.

\section{Chaos and Quest in Migration-Determining Moments}

When returning to Frank's narrative typology, we may see that both chaos and quest characterize Syrian stories of departure and migration-determining moments. As an existential term in extremis, chaos is evocative of the complete sense of disruption and disorder, what Bakhtin has called "crisis time" or "turning points and catastrophes" of life (1984, 169 and 149). It denotes the sensation of being thrust into the arbitrariness of existence, to that which lies beyond one's desire and control. As such, it is reminiscent of what Martin Heidegger has called a Geworfenheit, or a "thrownness" of being (1962, 219-24), i.e., being thrown into or caught up by circumstances in the arbitrariness of life. However, as evidenced in the following stories, chaos may also generate motivations, opportunities, and a host of different choices that can induce hope and prove existentially lifesaving.

Said explains that he experienced a third pivotal episode which ultimately sparked his decision to leave Syria for good:

During Ramadan in 2015, my big brother was taken by the Shabiha [militias working for the Syrian government] and brought to al-Mezze ${ }^{13}$. We all knew what this meant; he might be dead already, and if we tried to find him, it could be dangerous. [...] We heard so many stories, so many were missing. [...] I kept looking for him, but one day I got a call from someone imploring me to get out of Syria since my name was on the list. And I had to do it fast before my name would be circulated to all the checkpoints.

This sudden turn of events became a decisive moment for Said, one that he describes as "extremely challenging." Not knowing what fate had befallen his brother and the rest of his family scattered around the country left him feeling guilty for leaving them all behind. "For me, it was a very difficult decision to leave Syria," Said says, "but I didn't have any other solution. It was a matter of life and death."

For Bassem, the decision to leave his native country was equally hard. On the one hand, there were the "endless bombings, shootings, and mortar shells," he recalls, "and wherever I moved, these sounds followed me." However, what really sparked the beginning of Bassem's migration journey was a notice to serve in the regime's military forces. "Serving in the military is actually compulsory," he explains, "so if you don't enroll, the regime will catch you and imprison you immediately." Bassem did not want to wage war, to kill or be killed. Thus, to avoid being drafted, he went into hiding for one year, in various places, and through different acquaintances. The fear of being caught and the dread of living in such confined and temporary conditions finally left him desperate to leave Syria. Bassem secured a tourist visa to Egypt, which gave him a safe, albeit emotionally charged passage out of the country:

13 Al-Mezze is a military base on the outskirts of Damascus, including a notorious detention centre that both prior to and during the Syrian civil war has been used as a prison for political dissidents and others. As with other Syrian detention facilities, numerous reports attest to severe torture and inhumane treatments at this centre. See the account of Salem Mdlala, "Al-Mezze Prison was hell": Refugee today website. Accessed March 26, 2021. https://www.refugee.today/torture/al-mezzeh-prison-a-torture-chamber. 
"That airlift was a ticket to freedom, but also the beginning of a long separation. (...) Since then, I have been separated from my whole family."

Akram, a middle-aged and religiously devout Sunni Muslim, has a similar story of despair regarding his departure from Syria. He used to live in the governorate of Homs with his wife and seven children at the time of the war. "We were like neutral, you know, and different groups started to harass me, wanting me to join the one or the other." After being imprisoned for some time, he recognized the risks had gotten too high, and there was no other way than to migrate. With no income, it was difficult to find money that could finance the trip for him and his family. They had multiple stops in different locations in Syria, always relying on the hospitality and help of family and friends along the way. He recalls this process of internal displacement as a journey of persistent fear:

It was fear on all the roads leading out of Syria because you don't know for what reason you may suddenly lose your life or gain your freedom. I went through a lot of places where the regime had control and other places where the opposition had control. I feared them all. And then, of course, there were the places of ISIL that also scared us. [...] You feel two things: the urge to get out of fear and the need to get to safety.

These departure stories confront us with the composite fact that any decision to leave Syria is fraught with a highly mixed set of reasons and existential uncertainties. Recent research shows migration timing deals with more than the binary options of "fight and flight" but entails "large repertoires of protection strategies" (Schon 2019, 12). Many contemporary migration scholars agree migration-determining factors move along a dynamic spectrum between push and pull factors, blurring the lines between previously clear-cut understandings of forced vs. voluntary migration (Erdal and Oeppen 2018). My participants' stories show that "degrees of volition and constraints are constantly at play" (Erdal and Oeppen 2018) in their decisionmaking. For many of the interlocutors, leaving Syria was not the desired outcome, nor was it an easy decision to make. Instead, many postponed such a decision to the last minute, and/or endured multiple internal displacements before finally seeing no other option than to escape.

Common denominators in all my interlocutors' stories are general feelings of fear and insecurity, of not wishing to take part in the war and of being at the mercy of different parties to the conflict. Fear is all-pervasive in the stories of Said and Akram, with the dread of imprisonment and torture finally prompting them to leave Syria. Akram depended on hospitality but was surrounded by hostility, and describes how fear accompanied him on "all the roads leading out of Syria". On the other hand, Bassem feared being drafted and to live in continuous hiding. In fact, we see that these "narratives of fear" (Pearlman 2016, 2017) are themselves powerful drivers of migration, as they refer to both self-experienced confrontations with violent situations and to imagined and perceived forms of fear-inducing threats. Additionally, fear is intimately connected to issues of religious identity in the interlocutors' stories. It brings forth loyalties and linkages which forces both individuals and groups to (re)negotiate in an increasingly sectarianized environment. Furthermore, as Said recounted, there were "so many stories" circulating, pointing towards a broader narrative landscape in which stories and rumors contribute to reinforcing different modalities of fear. According to Justin Schon (2019), the circulation of social narratives may condense into "narrative ruptures" that often correspond to the timing of motivation to migrate. People tend to remember these existentially 
decisive moments where one's life course changes and literally takes a new direction (2019, 22).

\section{Journeying into the Unknown-Narratives of Refugeehood}

In the following samples of Syrian migratory experiences, it will be apparent that the precariousness of life does not necessarily cease to exist after crossing the Syrian border. Instead, chaos is exceedingly discernible during displacement, both inside and outside of Syria. It continues in different forms and at different places, whether in the confinement of neighboring refugee camps, in navigating new and alien terrains, or journeying across land and sea in search of safer havens. The journalist and former refugee Omar al-Muqdad (2017) subsumed these harrowing experiences of displacement under one descriptive heading: "A tormented journey into the unknown."14

\section{Between Life and Death-The Heterotopia of Migration}

From the time of escape to relocation in exile, forced migration may be seen as a profound series of existentially charged and liminal moments intersecting the experiences of refugees at every stage of their journey. Along the continuum of vulnerability and resilience, religion and identity re/de-constructions play ambiguous roles in displacement stories, swaying dynamically between processes of transformation, adaptation, and resistance. We remember that for Said, leaving Syria was dramatic and rapid, and he quickly had to evaluate possible escape routes out of the country. He took a plane to Egypt and continued to Turkey from there. "It was risky," he recalls, "as I could easily be taken hostage at the airport, and I'd be dead if they arrested me." He explains how his initial migration journey was a traumatic experience veering between the fear of death and the hope for a safe exit:

The hardest part of the journey was going from my house to the airport until I got on the plane. I remember there were 15 checkpoints, and for each passing, I was scared to death of being stopped and interrogated. [...] It was miraculous, thanks to God, I passed them all, and I felt like I was born again! [...] When the airplane took off, this moment was worth the world to me!

Following in the footsteps of so many other Syrian refugees, Turkey was a necessary stopover for Said as he intended to try the sea-bridge to the European continent. Weeks passed while he looked up smugglers and tried to find the right moment and the proper harbor from where to cross over to Greece. However, just before embarking in the dingy, Said changed his mind and regretted his decision:

It was all dark, and the wind was catching up. We were all given these useless life-vests filled with cotton [...], and the boat had no captain. [...] I wanted to go back, but the smugglers threatened me at gunpoint to enter [the boat]. [...] I thought to myself that okay, if my life ends now, I'd prefer to die here than to die by torture [in Syria].

Said, measuring the odds for failure, calls this part of the journey "God's miracle." He

14 Omar Al-Muqdad. 2017. "The Syrian Refugee Experience: A Tormented Journey into the Unknown”: Centre for Migration Studies. Accessed March 26, 2021. https://cmsny.org/publications/al-muqdad-120717/. 
arrived safely on one of the Greek islands, where the grief and despair of people onshore welcomed him. It turned out that another boat had just capsized, and two of four children in a Syrian family had drowned. "I will never forget the frantic cries of the mother," Said recalls, "there was no end to her tears."

When Akram had left Syria, he recalls that a new set of mixed emotions took hold of him:

On the border to Turkey, I had the feeling of being a foreigner for the first time in my life. I felt safe there, but at the same time, you start to think about the good things you're missing in your country. You know you can't go back, and you feel a sense of hopelessness. [...] You start to get another kind of fear, because now you have to look for a life and a future for the children, to get a job, and then your mind starts to wander off again. [...] I realized I needed more safety, more predictability in life.

At this point, Akram left his family behind in Turkey and joined the many refugees who had set their eyes on Europe. He pondered the idea of paving the way for his family as there could be better life options elsewhere. In his idealization of the new opportunities, Akram did not consider what difficulties awaited him along his continued refugee journey.

I found that the only solution is to go to Libya, although this turned out to be one of the most dangerous routes. [...] I traveled 40 days in the desert between Algeria and Libya, and there you discover that your life is entirely in the hands of armed bandits. They exchange you from one to another, and this is so scary that I remember how we all wanted to die, and that's it. [...]

Akram wanted to go back to Turkey, but the human traffickers had taken all his money and he felt trapped in a no-man's-land, not being able to move forward to Italy nor go back to reunite with his family. "I think this is the worst feeling one can have," Akram recalls, "to arrive at a point where you feel that your life story has ended."

Mahmoud echoes that similar feeling of being trapped. A former atheist with a Sunni Muslim background, the years of war brought Mahmoud's former life to a complete standstill. He lost his work, his home, and regime forces killed many of his close relatives. He also lost a sense of himself, he says, as "everything around me was just growing and growing, and there were no places to hide." The exit out of Syria was fraught with danger, but he ended up in Istanbul, where he stayed for two years. He describes these years of temporary exile as "miserable." Haunted by memories from his past and disempowered by the ever-deteriorating news from Syria, his experiences are reminiscent of a symbolic death. Instead, hatred entombed his mind and filled the empty spaces left behind after losing everything and everyone he had cherished. Mahmoud primarily directed his bitter resentment towards the Syrian regime and all the Alawites who represented and supported it. At the same time, it troubled him to see the increasing extremism and cruelty among those fighting the regime. "No one was looking out for Syria," he laments, "no one was caring for the country."

In these stories of forced migration, we receive a glimpse of how fear and despair constitute an omnipresent reality enveloping refugee experiences. Said explains how escaping Syria summoned the extremities of two contradictory reactions: being "scared to death" and being "born again". Akram describes the fear of not being able to provide for his family as a trigger for his continued journey into the precariousness of refugeehood. The feeling of being trapped, 
cornered, or thrust into a void of suffering epitomizes the very vulnerability of existential ruptures that many refugees endure along the way. Nowhere, perhaps, is the vulnerability more acutely felt than during distilled experiences of life and death, such as in Said's story of his Mediterranean boat journey. In Lynda Mannik's words, boat migration constitutes a space reserved for moving "nowhere and somewhere at the same time" $(2016,140)$. In what has been named "the world's deadliest sea crossing" 15 , we may regard these voyages as symbolic representations of what Michel Foucault has termed 'heterotopias'-the boat itself being "the heterotopia par excellence" as it is "a floating piece of space, a place without place that exists by itself, that is closed in on itself and at the same time is given over to the infinity of the sea" $(1986,27)$.

Alongside the terrifying sensation of fear, the migration narratives also mirror profound aspects of transformation, choices, and redirections. Borrowing on Frank's typology, experiences of chaos are profoundly ambiguous as they correspondingly give way to different forms of quest. Frank draws on Arnold van Gennep's concept of rites de passage as a way of characterizing "departure from known to unknown territory (...), initiation into the various and transforming trials of suffering (...), and eventually a return to a changed and awakened state of being" ([1995] 2013, 118). The concept of liminality, with its spatiotemporal connotations of something existing "betwixt and between" (Turner 1967, 93), contains significant references to the ambiguous realm of refugees as liminal personae, or "threshold people" (Turner 1995, 95). From their own experiences as refugees, Yanery N. Vigil and Catherine B. Abidi describe refugeehood as being in the middle of a "vulnerability-resiliency contradiction" $(2018,56)$. It is a paradoxical state of being where one's sense of identity dissolves to some extent, bringing about uncertainty and fear, but also the possibility of new perspectives. Similarly, Mannik (2016) points to the undetermined state of refugeehood as "a negative, soulless void, where suffering reigns, and conversely, an empty space where new cultural identities emerge" (2016, 139).

As a prism for understanding the existential dimensions of Syrian displacement trajectories, the ambiguous realm of liminality corresponds with the concept of heterotopia on multiple levels. When viewed from a narrative point of view, heterotopia becomes a mirror image of the worlds within worlds that characterize the heterogeneity of displacement stories. As a spatial term, it invocates the floating pieces of lived realities, and may thus function as an illuminating metaphor for understanding the paradoxical, contradictory, and marginal dimensions of my interlocutor's ruptured life-courses.

\section{Migration as a Theologizing Experience}

Many of the liminal refugee experiences I have encountered strike to the core of the identityshaping inter-relationship that exists between religion and forced migration. For some, religious faith, fellowship, and practices contribute to filling the empty spaces of displacement, providing resilience and comfort in the face of chaos. Issues of religion may even turn into

15 Amnesty International UK, 2018. Accessed March 26, 2021. https://www.amnesty.org.uk/worlds-deadliestsea-crossing-mediterranean. According to the "Missing Migrant Project" by International Organization for Migration (IOM), 19,236 individuals lost their lives crossing the Mediterranean from 2014 to 2019: International Organization for Migration (IOM). Accessed March 26, 2021. https://missingmigrants.iom. int/. See also the fresh report provided by The University of Warwick, in which migratory journeys and experiences across the Mediterranean are thoroughly documented: University of Warwick report. Accessed March 26, 2021. https://warwick.ac.uk/fac/soc/pais/research/researchcentres/irs/crossingthemed/ctm_f inal_report_4may2017.pdf. 
outright lifesaving strategies. Thomas Hylland Eriksen provides a particularly apt metaphor for such strategies of survival when he describes them as a task of "rebuilding the ship at sea" $(2010,12)$. We remember that, for Mahmoud, there was initially no space for God in his state of despair while living in temporary exile. Nevertheless, it was at this low point in life that a new religious identity emerged and faith, in his words, "saved" his state of mind and became a ventilation system:

My wife helped me to get into Islam, real Islam, so I started to pray and read about Islam and in the Qur'an, and I learned that it is never allowed to kill someone unless that person is personally attacking you or your family. [...] For me, even though I have hatred for the Shiites and the Alawites, I don't feel readiness to kill any of them, why? Because I want to follow the right Islam.

Mahmoud explains how this new direction in life was something that continued to guide him through his refugee journey and even after resettlement in Norway: "Religion has helped me to calm down my hatred in a way. It gives my soul some peace to pray."

Akram remembers how religious companionship among fellow traveling refugees helped him overcome many of the emotional obstacles, despite the many trials. "I got to know many Muslims along the way," he says, "and we stayed together, we prayed and encouraged each other." In particular, when undertaking the dangerous boat journey from Libya to Italy, staying and praying together was paramount:

[...] they took us into these wooden boats, and everybody was scared and read all verses of the Qu'ran. We didn't feel safe until we saw the coastline. It was only at that moment I could breathe again and think that now I can go on with my life. So from there on, God made it easy for me - alhamdulillah.

For Said, his migratory journey continued to Macedonia and on to Serbia. Twenty-three times he tried to cross the Hungarian border, but each time the guards turned him and the others back. These days in limbo are blurred in Said's memory, as he remembers having wandered somewhat aimlessly in woodlands, hungry and constantly wet from the rain. "There was no relief," Said remembers, "I didn't relax any day." However, like Akram, Said talks about religion and companionship as a safety net during these days of agony:

I remember we used to hide in the woods, and we tried to sleep during the days and start walking when it was dark. [...] We were a group of Syrians, and we prayed together, [...] it was a way of keeping track of time, but we didn't do it in plain sight. [...] We didn't want anyone to see us and get suspicious.

In these stories, we see that God is reflective in the language used to describe experiences of migration. Both Akram and Said are practicing Muslims, and while Said refers to his continued existence as "miraculous," both praise a divine power when other words fail to express survival in confrontation with death. According to Samuli Schielke (2018), an anthropology of destiny is involved when faced with life-rupturing events. For many Muslims, belief in destiny means to "submit to, and trust, an omnipresent, benevolent God," and seek divine alliance in "the face of overwhelming circumstances" (Schielke 2018, 344 and 346). In a similar vein, Gerhild Perl (2019) demonstrates that the use of religious vocabulary in migration stories forms part of a "semantic of survival," or a way of positively framing extraordinary events 
in terms of religious gratitude (Perl 2019, 19). These aspects are also present in Mahmoud's story. Consumed by hatred and despair, gratitude is reflected in existential terms when he describes how religion and faith literally "saved" his state of mind. Indeed, we are reminded of what Timothy Smith has called a "theologizing experience" when looking at how religion may provide resilience and hope in response to trauma, loss, and violent uprooting (Smith 1978 in Frederiks 2016, 186). Faith, according to Martha Frederiks, may thus turn into a powerful language that offers the necessary "vocabulary" for expressing volatile migratory experiences (2016, 186-88).

For some of my interlocutors, religion also operates on a more communal level during their migration trajectories. When Akram recalls his forty days in the desert filled with smugglers and vulnerability, it brings forth an association with the Biblical prophets that were challenged and tested in a God-forsaken wilderness. However, for Akram religious companionship accompanied these trials, and strengthened his endurance and provided him with emotional encouragement. Likewise, Said reflects on how a common faith brought the refugees closer together and how daily prayers offered them some structure in an otherwise timeless and drifting existence. Their experiences are reminiscent of what Victor Turner termed the sacred component of "communitas," in which existential phases of transition can lead to shared forms rituals and togetherness (1995). This fellowship notwithstanding, Said reveals that prayers were performed in hiding as they did not want anyone to "get suspicious." This statement could be interpreted in several ways. Still, it may point to having to conceal one's identity in the face of increasing forms of Islamophobia and racism directed against Muslim migrants trying to enter Europe. ${ }^{16}$ In that case, it falls within the growing importance of religious identity in the European politics of migration, and distinguishing between "good/bad Muslims" in popular refugee discourse (Wilson and Mavelli 2017, 5-6). We may also interpret Mahmoud's conversion story as a way of distancing himself from the Muslim's "bad" reputation when he represents his own version as the "real" and "right" form of Islam.

\section{Narratives of Restitution or Hope?}

When returning to Frank's typology of chaos, quest, and restitution, we have seen that one of the vital aspects of refugee experiences is managing and navigating (religious) identities in the face of new and fragile contexts. Borrowing Reinhart Koselleck's terms (2004), we might say that chaos, as a "space of experience," can give way to different forms of quests and generate new "horizons of expectations" (2004, 261). But how does Frank's description of restitution narratives merge into such a horizon? In my interlocutors' stories, there appears to be less evidence for restitution to take place in the full sense of this term. The empirical material finds no traces of a reestablishment of the status quo, nor expectations of a future that fixes the present disorder by restoring the normalcy of the past.

For Maryam, the discrepancy with the past is absolute and something she gets painfully reminded of during her migration journey. Unlike Said and Akram, she experienced no religious companionship or mutual support while traveling across borders to safer havens. On the contrary, when asked whether Syrians stuck together during the migratory journey, Maryam replied, "No, no, not at all! We were all separated in our minds." She provides an example of

16 There are both qualitative and quantitative studies documenting such perspectives of religious intolerance in the wake of the current refuge crisis. See, for example, Farid Hafez (2015), Elizabeth Shakman Hurd (2017), and the European Islamophobia Report (2019). 
the growing alienation between individuals by recalling a conversation she had while living in Greece:

I was talking with a friend about the situation in Syria. He is opposed to the President, whereas I'm supporting him. I was just talking rationally about what was really going on, and he was a very respected person to me, one of my best friends. [...] But then he said: 'Huh, just because you're Christian and he [the President] is supporting you, you're with him.' It was like slapping me in the face, and I told him: 'No, not because I'm Christian, because I love Syria!' I love Syria and cannot pretend to hide what it gives us.

Maryam's feelings of distrust followed her during her migratory journey and made her question the legitimacy of some refugees she met along the way:

Most of the people who took part in the war are spread around Europe and the rest of the world now. They woke up after one or two years fighting with the [Free] Syrian Army and realized there was no way the President would go away. [...] I met a lot of them on my way, and I could see from their look and their attitude that they have blood on their hands, and now they are asking for protection.

These experiences have led Maryam to reassess not only her own minority identity but that of others when relating socially to fellow Syrians in exile. "I want to tell you honestly," she clarifies, "that all the smaller groups [Christians, Kurds, Alawites, and Druze] have come closer to each other now because we share the same destiny as minorities."

Said, too, after all his travels and travails, struggled to find meaning and purpose in his migratory journey. After finally traversing Hungary, he continued more easily on through Austria and Germany, and from there to Norway. However, the uncertainty and tension lingered and nowhere did Said have any sense of arrival or safety. Instead, this final part of his migration journey was mixed with new sensations of loss as the friends he had acquired during his sojourn in the woods, one by one, hopped off at different destinations along the way. "I felt empty," Said reflects, “[...] I was heading on, but didn't know what to expect and where I'd find some rest."

In Maryam's story, we see that instead of finding comfort and togetherness among fellow Syrian travelers, Maryam experiences the exact opposite: separation. Hers is a tale of alienation and mistrust in contrast to the conviviality she experienced among people with different ethno-religious origin before the war. For Maryam, there is a growing feeling of identity exclusion, perceived both self-experientially as a minority Christian, but also politically when being rebuked for her support of the ruling regime. Although she bewails that "Syrians have a problem with each other," her frustration receives a discernible sectarian face when she delegitimizes some [Muslim] refugees as having "blood on their hands." We may understand her experiences as a response to the extreme violence of the Islamist opposition groups in Syria that left many minority groups at perilous risk of religious and political persecution (Bandak 2015; Schmoller 2016). Such an understanding also serves to explain how Maryam, seeking safety and social support in exile, identifies more closely with other Syrian minority groups.

Said's and Akram's stories confront us with another non-restitutional aspect of forced displacement. To enter a foreign land and travel along paths hitherto unknown instigates emotions familiar to many refugees, namely the feeling of being a complete stranger and having to start life all over again. Indeed, as Maria C. La Barbera states, migrants often feel "lost, alone, 
and without reference points" while transiting through or resettling in receiving countries $(2015,3)$. This can lead to disillusionment regarding the future and contribute to nostalgic memories of the past, "idealizing the country of origin" (La Barbera 2015, 3; Arvanatis and Yelland 2019, 3). While both Akram and Maryam show traces of utopian longing for a Syria of the past, they both know it is impossible to return home to life as they knew it. The topos in their utopian yearning is, to paraphrase Zygmunt Bauman (2003), no longer there; it is left in ruins and thereby irrevocably lost.

When replacing restitution as a viable concept in our narrative inquiry, I do not seek to disregard the future as an agentive feature in forced displacement stories. Instead, what needs to be addressed is that migration entails both future-oriented and backward-looking processes involving movement between different spaces and temporalities (Pine 2014). While these processes may not entirely represent narratives of restitution in my empirical material, it does not mean that forms of temporary restoration are altogether absent in different phases of migratory experiences. In my study, migration processes align themselves more with the narrative juncture of hope and despair. Frances Pine convincingly explains how these contradictory emotional states are simultaneously at play in migrants' trajectories:

Hope is a complex, many-layered notion resting on the capacity for imagination, on a sense of time and of temporal progress, on a desire to believe in a better future or in the possibility that something can change, and to some extent on uncertainty. Hope is also always mirrored or shadowed by its opposite, despair. $(2014,96)$

Refugee narratives may veer between sensations of dystopia and utopia, insecurity and security, immobility and mobility, despair, and hope-but it is in the in-between of chaos and quest that refugees often execute their agency in the face of prevailing constraints. Thus, the term heterotopia may well be a more suitable metaphor for encapsulating these at once simultaneous and contradictory forces that play themselves out in Syrians' migratory experiences. The lived dimensions of religion are intimately connected to these processes of liminality in displacement. On the one hand, we have seen how issues of religion and processes of religious (re/de)identification can offer resilience and comfort, acting in ways that provide both orientation and socio-psychological coping amidst moments of fear and devastation. On the other hand, religion can serve purposes at once destructive and treacherous, fostering processes of identity othering and inflicting violence and hatred. Finally, we need to remember that the role of religion, whether perceived positively or negatively in the trajectories of Syrian refugees, is but one of many aspects related to the existential discontinuities of displacement. Above all, as Said poignantly expressed, forced migration constitutes broken journeys in which there is no real "relief" or relaxation, rendering hope a liminal space in between the forces of chaos and quest.

\section{Conclusion}

This study has argued for a polyvocal and narrative approach when investigating how religion and identity (re/de)constructions are entangled with the Syrian refugee crisis and mirrored in the diversity of Syrian refugee experiences. It has called for a more existentially oriented framework to provide a deeper understanding of how people, through storytelling, reflect on the tensions and paradoxes of conflict-induced displacement. By conversing with a theory of chaos, quest, and restitution in refugee narratives, the empirical analysis reveals that issues of 
religion and religious identification processes occupy significant, albeit diverse, roles in Syrian migration trajectories. The (dis)empowering role of lived religion attests to types of dynamics operating on both internal subjective levels as well as on external and socio-political levels, crosscutting into the different times and spaces of displacement. Stories of religious identity inclusion/exclusion move ambiguously along a continuum where both extreme forms of vulnerability and agency may exist simultaneously. Thus, while we may determine that religion is dynamically interwoven in Syrian refugee experiences before and during forced migration, my investigation shows these interconnections operate on multiple levels, in contested ways, and during moments considered existentially pivotal.

This research is limited to an exploration of refugee trajectories prior to resettlement in Norway as a destination country. Hence, there is an element of non-finality to the stories and voices with which we have become acquainted. For the participants taking part in this study, their migratory journeys have continued into exile, where new spaces of experience have generated new stories and different horizons of expectation. When attempting to (re)assess the role of religion and identity processes in these new destination contexts, further research is urgently needed. Seeing that the tragedy of the Syrian refugee crisis is still unfolding, and that Syrians now comprise one of the largest refugee populations in Europe and elsewhere, scholarly efforts must continue towards an enhanced understanding of spiritual, inter-religious, existential, and transnational dimensions of Syrians' life in exile.

\section{References}

Al-Muqdad, Omar. 2017. "The Syrian Refugee Experience: A Tormented Journey into the Unknown." Centre for Migration Studies. https://doi.org/10.14240/cmsesy120717.

Ammerman, Nancy. 2016. "Lived Religion as an Emerging Field: An Assessment of Its Contours and Frontiers." Nordic Journal of Religion and Society 29 (2): 89-99.

Arvanatis, Euginia, and Nicola Yelland. 2019. "Home Means Everything to Me ...': A Study of Young Syrian Refugees' Narratives Constructing Home in Greece." Journal of Refugee Studies fez030. https://doi.org/10.1093/jrs/fez030.

Bakhtin, Mikhail. 1981. The Dialogic Imagination. Edited by Caryl Emerson and Michael Holquist. Austin: University of Texas Press.

— 1984. Problems of Dostoevsky's Poetics. Edited and translated by Caryl Emerson. Minneapolis: University of Minnesota Press.

Bali, Zeina. 2015. "Domination, Privilege and Fear. Uncovering a Hidden Curriculum of Oppression in the Syrians' Narratives on School." Master Thesis, Lund: Lund University.

Bamberg, Michael. 2016. "Narrative Inquiry: Interview with Michael Bamberg." Europe's Journal of Psychology 12 (1). https://ejop.psychopen.eu/article/view/1128/pdf.

Bandak, Andreas. 2014. "Of Rhythms and Refrains in Contemporary Damascus: Urban Space and Christian-Muslim Coexistence." Current Anthropology 55 (12): 248-61.

— 2015. "Reckoning with the Inevitable: Death and Dying Among Syrian Christians During the Uprising." Ethnos 80: 671-91.

Bartels, Edien, Kim Knibbe, Martijn de Koning, and Oscar Salemink. 2015. "Cultural Identity as a Key Dimension of Human Security in Western Europe: The Dutch Case." In A World of Insecurity: Anthropological Perspectives on Human Security, 116-32. London: Pluto Press. 
Bauman, Zygmunt. 2003. "Utopia with No Topos." History of the Human Sciences 16 (1): 1125.

Beaman, Lori G., Jennifer A. Selby, and Amélie Barras. 2017. "No Mosque, No Refugees. Some Reflections on Syrian Refugees and the Construction of Religion in Canada." In The Refugee Crisis and Religion. Secularism, Security and Hospitality in Question, edited by Luca Mavelli and Erin K. Wilson, 77-96. London: Rowman \& Littlefield International.

Beckford, James A., ed. 2015. Migration and Religion. Vol. 1. Cheltenham: Edward Elgar Publishing.

Brubaker, Rogers. 2015. "Religious Dimensions of Political Conflict and Violence." Sociological Theory 33 (1): 1-19.

Brubaker, Rogers, and Frederick Cooper. 2000. "Beyond 'Identity,'." Theory and Society 29 (1): $1-47$.

Castles, Stephen. 2012. "Understanding the Relationship Between Methodology and Methods." In Handbook of Research Methods in Migration, edited by Carlos Vargas-Silva, 7-25. Cheltenham: Edward Elgar Publishing.

Crawley, Heaven, and Katharine Jones. 2020. "Beyond Here and There: (Re)conceptualising Migrant Journeys and the 'in-Between'." Journal of Ethnic and Migration Studies. https: //doi.org/10.1080/1369183X.2020.1804190.

Daiute, Colette. 2014. Narrative Inquiry. A Dynamic Approach. Thousand Oakes, California: SAGE Publications.

Day, Abby, and Lois Lee. 2014. "Making Sense of Surveys and Censuses: Issues in Religious Self-Identification." Religion 44 (3): 345-56.

Demmers, Jolle. 2017. Theories of Violent Conflict. An Introduction. London: Routledge.

Denizeau, Laurent. 2017. "Considering Human Existence. An Existential Reading of Michael Jackson and Albert Piette." In What Is Existential Anthropology?, edited by Michael Jackson and Albert Piette. Oxford: Berghahn Books.

DeSantis, Alan. 2001. "Caught Between Two Worlds: Bakhtin's Dialogism in the Exile Experience." Journal of Refugee Studies 14 (1): 1-19.

Drønen, Tomas Sundnes. 2018. "Christian Migrant Communities. Transnational, Transcultural, and Translocal Discourses of Change." Method and Theory in the Study of Religion 30 (1): 227-51.

Eastmond, Marita. 2005. "The Disorders of Displacement: Bosnian Refugees and the Reconstitution of Normality." In Managing Uncertainty. Ethnographic Studies of Illness, Risk and the Struggle for Control, edited by Vibeke Steffen, Richard Jenkins, and Hanne Jessen. University of Copenhagen: Museum Tusculanum Press.

Ebaugh, Helen Rose. 2010. "Transnationality and Religion in Immigrant Congregations; the Global Impact." Nordic Journal of Religion and Society 23 (2): 105-19.

Ebaugh, Helen Rose, and Janet Saltzman Chafetz. 2002. Religion Across Borders: Transnational Immigrant Networks. Walnut Creek, California: AltaMira Press.

Eghdamian, Khatereh. 2016. "Religious Identity and Experiences of Displacement: An Examination into the Discursive Representations of Syrian Refugees and Their Effects on Religious Minorities Living in Jordan." Journal of Refugee Studies 30 (3): 447-67.

Erdal, Marta Bivand, and Ceri Oeppen. 2018. "Forced to Leave? The Discursive and Analytical Significance of Describing Migration as Forced and Voluntary." Journal of Ethnic and Migration Studies, Special Issue: Aspiration, Desire and the Drivers of Migration, 44 (6). 
Eriksen, Thomas Hylland. 2010. "Human Security and Social Anthropology." In A World of Insecurity. Anthropological Perspectives on Human Security, edited by Thomas Hylland Eriksen, Ellen Bal, Oscar Salemink, and O. Salemink. New York: Pluto Press.

Fahmi, Georges. 2018. "The Future of Syrian Christians After the Arab Spring." Technical Report, Middle East Directions (MED), 2018/04.

Fiddian-Qasmiyeh, Elena, ed. 2020. Refuge in a Moving World. Tracing Refugee and Migrant Journeys Across Disciplines. UCL Press. https://doi.org/10.14324/111.

Fina, Anna de, and Amelia Tseng. 2017. "Narrative in the Study of Migrants." In The Routledge Handbook of Migration and Language, edited by Suresh Canagarajah, 381-96. New York: Routledge.

Foucault, Michel. 1986. "Of Other Spaces." Translated by Jay Miskowiec. Diacritics-a Review of Contemporary Criticism 16 (1): 22-17.

Frank, Arthur W. 2008. "The Problem of Saying Something About Trauma and Narratives: Witness Versus Analysis." June 7, 2008. Ritsumeikan University. Keynote speech delivered at the Symposium "Narrative, Trauma and Ethics: Welcoming Dr. Arthur W. Frank.", Ritsumeikan University. http://www.ritsumeihuman.com/hsrc/resource/01/pdf/01.

— 2010. Letting Stories Breathe. A Socio-Narratology. Chicago: The University of Chicago Press.

—. (1995) 2013. The Wounded Storyteller. Body, Illness \& Ethics. 2nd ed. Chicago: The University of Chicago Press.

Frederiks, Martha. 2016. "Religion, Migration and Identity. A Conceptual and Theoretical Exploration." Mission Studies 32 (2): 181-202.

Giddens, Anthony. 1991. Modernity and Self-Identity. Self and Society in the Late Modern Age. Cambridge: Polity Press.

Godžiak, Elzbieta M., and Dianna J. Shandy. 2002. "Editorial Introduction: Religion and Spirituality in Forced Migration." Journal of Refugee Studies 15 (1): 129-35.

Hafez, Farid. 2015. "The Refugee Crisis and Islamophobia.” Insight Turkey 17 (4): 19-26.

Hagan, Jacqueline Maria. 2012. "Religion on the Move: The Place of Religion in Different Stages of the Migration Process." In Handbook of International Migration, edited by Steven J Gold and Stephanie J. Nawyn. New York: Routledge.

Hall, S. 1990. "Cultural Identity and Diaspora." In Identity, edited by Jonathan Rutherford. Lawrence \& Wishart.

Heidegger, Martin. 1962. Being and Time. Oxford: Basil Blackwell.

Hermans, Hubert J. M., and Giancarlo Dimaggio. 2007. "Self, Identity, and Globalization in Times of Uncertainty: A Dialogical Analysis." Review of General Psychology 11: 31-61.

Hock, Klaus. 2008. "Religion on the Move: Transcultural Perspectives. Discourses on Diaspora Religion Between Category Formation and the Quest for Religious Identity." In Christianity in Africa and the African Diaspora. The Appropriation of a Scattered Heritage, edited by Afe Adogame, Roswith Gerloff, and Klaus Hock, 235-47. London: Continuum.

. 2011. "Discourses on Migration as Migratory Discourses: Diasporic Identities and the Quest for Analytical Categories." In African Christian Presence in the West. New Immigrant Congregations and Transnational Networks in North America and Europe, edited by Frieder Ludwig, J. Kwabena Asamoah-Gyadu, K. HockLudwig, F., and J.Kwabena Asamoah-Gyadu. Trenton, NJ: Africa World Press.

Holbraad, Martin, Bruce Kapferer, and Julia F. Sauma, eds. 2019. Ruptures. Anthropologies of Discontinuity in Times of Turmoil. London: ULC Press. 
Hurd, Elizabeth S. 2017. "Muslims and Others. The Politics of Religion in the Refugee Crisis." In The Refugee Crisis and Religion. Secularism, Security and Hospitality in Question, edited by Luca Mavelli and Erin K. Wilson, 97-108. London: Rowman and Littlefield.

Jackson, Michael, and Albert Piette. 2017. What Is Existential Anthropology? Oxford: Berghahn Books.

James, William. 1985. The Varieties of Religious Experience. Cambridge: Harvard University Press.

Koselleck, Reinhard. 2004. Futures Past: On the Semantics of Historical Time. New York: Columbia University Press.

La Barbera, Maria Caterina. 2015. "Identity and Migration: An Introduction." In Identity and Migration in Europe: Multidisciplinary Perspectives, edited by Maria Caterina La Barbera. Switzerland: Springer International Publishing.

Lems, Annika. 2016. "Placing Displacement: Place-Making in a World of Movement." Ethnos 81 (2): 315-37.

Levitt, Peggy. 2007. God Need No Passport. Immigrants and the Changing American Religious Landscape. New York, NY: The New Press.

Levitt, Peggy, Kristen Lucken, and Melissa Barnett. 2011. "Beyond Home and Return: Negotiating Religious Identity Across Time and Space Through the Prism of the American Experience." Mobilities 6 (4): 467-82.

Lischer, Sarah Kenyon. 2014. "Conflict and Crisis Induced Displacement." In The Oxford Handbook of Refugee and Forced Migration Studies, edited by Elena Fiddian-Qasmiyeh, Gil Loescher, Katy Long, and Nando Sigona. Oxford: Oxford University Press.

Lovatt, H. 2013. "De-Constructing National Identities in the Levant." Your Middle East. https: //yourmiddleeast.com/2013/11/06/the-conflict-in-syria-is-bringing-to-the-foreloyalt ies-.

Løland, Ingrid. 2019a. "Between Utopia and Dystopia: Sectarianization Through Revolution and War in Syrian Refugee Narratives." Religions 10 (188): 1-23.

—. 2019b. "Negotiating Paradise Lost: Refugee Narratives of Pre-War Syria - A Discursive Approach to Memory, Metaphors and Religious Identifications." European Journal of Cultural Studies. https://journals.sagepub.com/doi/pdf/10.1177/1367549419869352.

Mannik, Lynda, ed. 2016. Migration by Boat: Discourses of Trauma, Exclusion and Survival. New York: Berghahn Books.

Manojlovic, Borislava. 2010. "Dealing with Complexities of Identity Conflict: Contentious Narratives and Possibilities of Their Transformation." Human Security Perspectives 7 (1).

Matar, Dina. 2017. "Media Coverage of the Migration Crisis in Europe: A Confused and Polarized Narrative." IEMed. Mediterranean Yearbook 2017. https://www.iemed.org/observ atori/arees-danalisi/arxius-adjunts/anuari/med.2017/IEMed_MedYearbook2017_med ia_migration_crisis_Matar.pdf.

McGuire, Meredith. 2008. Lived Religion: Faith and Practice in Everyday Life. Oxford: Oxford University Press.

Miller, Jody, and Barry Glassner. 2016. “The 'Inside' and the 'Outside': Finding Realities in Interviews." In Qualitative Research, edited by David Silverman, 4th ed., 51-66. London: SAGE.

Nome, Frida A. 2016. "Making Islam in Times of Crisis. The Friday Sermon and the Syrian Uprising." PhD Thesis, Norwegian School of Theology.

Pearlman, Wendy. 2016. "Narratives of Fear in Syria." Perspectives on Politics 14: 21-37. 
2017. We Crossed a Bridge and It Trembled: Voices from Syria. New York: HarperCollins Publishers.

Perl, Gerhild. 2019. "Migration as Survival. Withheld Stories and the Limits of Ethnographic Knowability." Migration and Society: Advances in Research 2: 12-25.

Pine, Frances. 2014. "Migration as Hope. Space, Time, and Imagining the Future." Current Anthropology 55 (S9): 95-104. https://doi.org/10.1086/676526.

Rabo, Annika. 2012. “'We Are Christians and We Are Equal Citizens': Perspectives on Particularity and Pluralism in Contemporary Syria." Islam and Christian-Muslims Relations 23 (1): 79-93.

Schielke, Samuli. 2018. "Destiny as a Relationship." Journal for Ethnographic Theory 8: 34346.

Schmoller, Andreas. 2016. “" 'Now My Life in Syria Is Finished': Case Studies in Religious Identity and Sectarianism in Narratives of Syrian Christian Refugees in Austria." Islam and Christian-Muslim Relations 27: 410-37.

Schon, Justin. 2019. "Motivation and Opportunity for Conflict-Induced Migration: An Analysis of Syrian Migration Timing." Journal of Peace Research 56 (1): 12-27.

Sigona, Nando. 2014. "The Politics of Refugee Voices: Representations, Narratives, and Memories." In The Oxford Handbook of Refugee and Forced Migration Studies, edited by Elena Fiddian-Qasmiyeh, Gil Loescher, Katy Long, and Nando Sigona. Oxford: Oxford University Press.

Stolleis, Friederike, ed. 2015. Playing the Sectarian Card. Identities and Affiliations of Local Communities in Syria. Beirut: Friedrich-Ebert-Stiftung.

Sørvig, Bendik. 2017. Syria. Den Tapte Revolusjonen. Oslo: Forlaget Manifest.

Thomassen, Bjorn. 2014. Liminality and the Modern. Living Through the in-Between. UK: Ashgate.

Turner, Victor. 1967. The Forest of Symbols. Aspects of Ndembu Ritual. New York: Cornell University Press.

1995. The Ritual Process: Structure and Anti-Structure. New York: Aldine de Gruyter.

Tweed, Thomas A. 2006. Crossing and Dwelling. A Theory of Religion. Cambridge: Harvard University Press.

Van Dam, Nikolaos. 2017. Destroying a Nation: The Civil War in Syria. London: I.B. Taurus.

Van Liere, Lucien. 2009. "Patterns of Violence: Religion and the Framing of Differences." Scriptura 102: 471-81.

- 2011. "Fighting for Jesus on Ambon, Interpreting Religious Representations of Violent Conflict." Exchange-Organizational Behavior Teaching Journal 40 (4): 1-14.

Vasquez, Manuel. 2008. "Studying Religion in Motion: A Networks Approach." Method \& Theory in the Study of Religion 20 (2): 151-84.

Vigil, Yanery N., and Catherine B. Abidi. 2018. "'We' the Refugees: Reflections on Refugee Labels and Identities." Refuge: Canada's Journal on Refugees 34 (2): 52-60. https://doi. org/10.7202/1055576ar.

Volkan, Vamık. 2006. Killing in the Name of Identity. A Study of Bloody Conflicts. Charlottesville: Pitchstone Publishing.

Wedeen, Lisa. 2015. Ambiguities of Domination. Politics, Rhetoric, and Symbols in Contemporary Syria. Chicago: University of Chicago Press.

Wilson, Erin K., and Luca Mavelli. 2017. "The Refugee Crisis and Religion. Beyond Conceptual and Physical Boundaries." In The Refugee Crisis and Religion. Secularism, Security and 
Hospitality in Question, edited by Luca Mavelli and Erin K. Wilson. London: Rowman and Littlefield.

Wong, Diana. 2014. "Time, Generation and Context in Narratives of Migrant and Religious Journeys." Global Networks 14 (3): 306-25.

Yassin-Kassab, Robin, and Leila al-Shami. 2016. Burning Country. Syrians in Revolution and War. London: Pluto Press. 